\title{
Gesture based Interface between User and the Digital Device using Sixth Sense Technology
}

\author{
Bharatwaj V \\ Final Year B.Tech-IT \\ SCSVMV University \\ Kanchipuram
}

\author{
Guruvenkatesh S \\ Final Year B.Tech-IT \\ SCSVMV University \\ Kanchipuram
}

\author{
Srinivasan $\mathrm{K}$ \\ Assistant Professor of IT \\ SCSVMV University \\ Kanchipuram
}

\begin{abstract}
This paper deals with the working of gesture recognition and image processing using sixth sense device which also helps us to perform mobile computing applications with ease just by the help of colored caps worn on the tip off the fingers of the user. [1]The camera recognizes the color caps instantly and perform application related to the gesture action. The device not only perform application related to the gesture and it also used to toggle, zoom (in and out) and to capture picture.
\end{abstract}

\section{Key words}

Image processing, color caps, mat lab

\section{Introduction}

Sixth sense technology is the unseen world of digital world which includes our ability to understand the process behind these digital event. [1]We all seen world through our physical senses are of 5 types that includes smelling, sighting, taste, sound, feeling etc. other than this we tend to work or act to the signal or we call them as gesture we receive from the other end people. We the human often use these senses in our daily routine in our day to day life. This sixth sense technology fill the gap between the tangible digital computing device and user by interacting them using natural hand gesture. Thus we no need to be in a place to access the computer to interact we can work wherever we need to.[8] The concept given by Pranav Mistry about his application 'sixth sense' helped me getting brief idea to build my own sixth sense device. This is done using a camera that helps recognizing the gesture and a projector to project the real time application. Image processing is another phrase in, this also helps us to understand what digital computing device represents. All this together as an application help user to interact digital devices anywhere by using simple physical gestures.

\section{COMPONENTS}

[11]The devices that are used in Sixth Sense Technology are:
A. Web Camera.
B. Projector
C. Color Markers
D. Laptop or Personal Computer

\subsection{Web Camera}

It grabs the motion of the colored markers worn on the fingertips and tracks the user gestures. The camera recognizes pictures individually that the user makes with his/her hand. The camera then sends this data to the laptop or PC for processing the image. The camera performs a basic interface between laptop and the physical world.

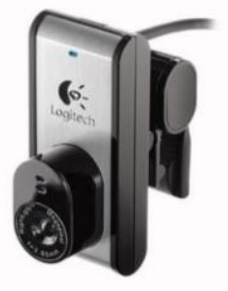

Fig1.0

\subsection{Color Markers}

These color markers placed at the tip of users fingers. Helps the webcam to recognize the hand gestures. The motion of the color markers is recognized and the gestures are preloaded data. According to the gesture applications preloaded are performed.

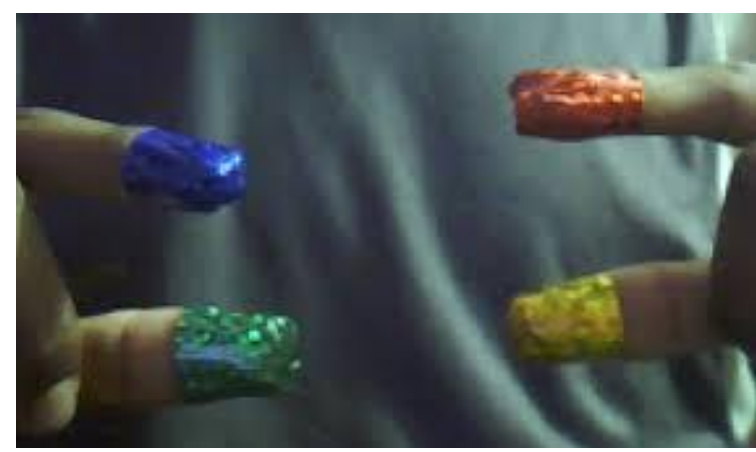

Fig1.1

\subsection{Laptop or Personal Computer}

The Laptop can be used for running or implementing the code written on the VB tools for executing the concept of image processing. The gestures done by the color marker are tracked by the camera and hence given to the laptop for further processing of the various applications are performed.

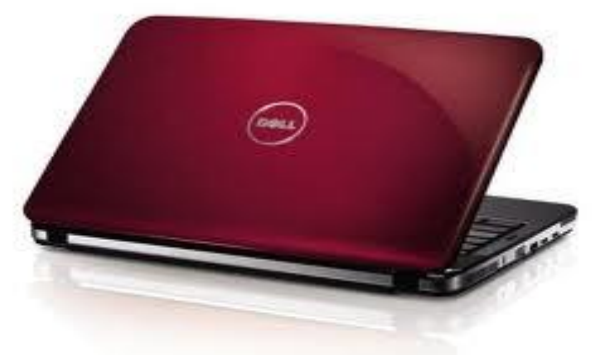

Fig1.2 


\subsection{Projector}

The projector plays as key output device of the Sixth Sense device. The projector is visually augments with physical object or wall to project digital information and graphical user interfaces. The mobile device provides the content that has to be displayed. The functions of the projector can be listed as:

- Projector projects graphical user interface of the selected application onto surfaces or any physical objects

- Related information are projected onto surface with help of physical gestures.

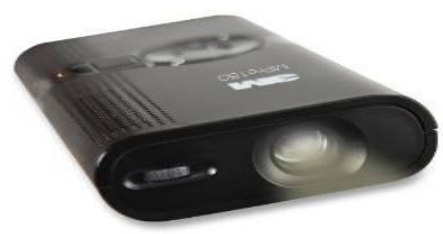

Fig1.3

\section{SIXTH SENSE TECHNOLOGY}

Sixth Sense technology is a different approach to computing and tries to make the digital aspect of our lives more interactive and over all, [4] they are natural while using. never mind about how complex the technology is, When we build their connectivity, we can get instant visual information projected onto any physical object that we pick up and the technology more about gestures, computer based algorithm etc.

\subsection{Gesture recognition}

Gesture recognition is a technology that interpret human gestures using interpolation algorithm, Gesture recognition enables humans to interface with the machine (HMI) and interact naturally without any mechanical devices. They can be originate from any bodily motion through face gestures or by hand gestures and hence use of mechanical or electronic appliances can be reduced and can able to connect with our physical world rather than sticking to one place.

\subsection{Computer vision}

On the other hand, computer vision describes the process software and hardware behind AI system. The software are used to track the gestures using some mathematical algorithm are been threshold into matrix form and produces 512 possible value to the captured image. By this way images are tracked and corresponding applications of the gestures are performed in real time.

\subsection{Construction And Working}

The methodology shown below in the algorithm used is based on the Sixth Sense Technology where user has to make several gestures using the finger worn color markers and perform real time actions whose images are been loaded in the program coding. [11] Main motivation is to move mouse pointer/cursor along with the user when his/her fingers, zooming images, capturing of photos using color caps. For this purpose, three components of Sixth Sense are used i.e. Camera, Colored Caps and MATLAB installed in Laptop

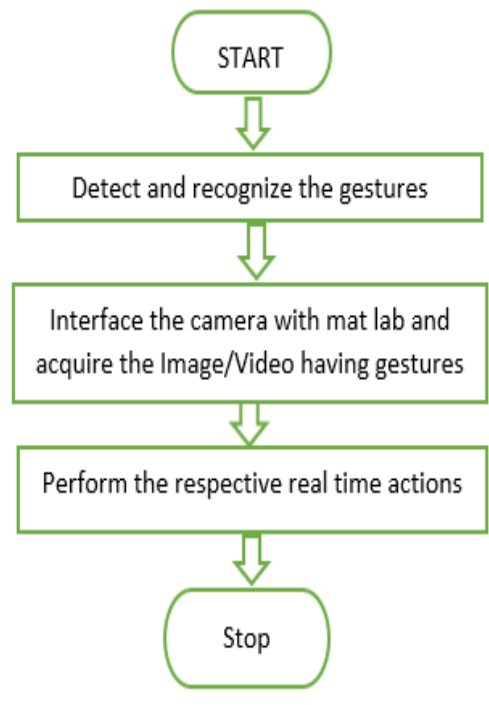

The approach works in a continuous manner where camera captures instant video and sends them to the laptop/ any digital device. MATLAB installed in laptop processes the input and recognizes the colors at the fingertips of the user. Following figure shows the algorithm we used in our approach to move cursor on screen, capture images using gestures and interfacing with the image for zoom in \& out.

In My proposed methodology, interaction with the physical world is done using camera and the Camera captures the video and starts recording them instantly and in continuation of recording it sends the video to VB program which is already installed in laptop which is connected with the camera. The code is prepared firstly converts the incoming video from camera into frames of images and slicing of video is done.[6] These images that are obtained from the slicing of video. These videos are then processed for color recognition process. The output image contain color caps that are worn in the finger. For this purpose, RGB values of the color caps value are calculated in the code and no other color will be detected in the image after color recognition except the caps colors and the background. The output images are displayed at 30fps and at the same speed as the speed slicing of video that are being captured, so it looks like a continuous movie in which the input is color values and the output is relevant application is performed. The color is then associated with the mouse cursor in code so that whenever the color moves in the output image from one pixel to another pixel, the mouse pointer position also get tracked by the color caps. In the same manner rest of the color is detected and actions performed to the relevant gesture. Similarly different gesture action are used to image toggle, zoom in and zoom out in images are performed.

\section{INTERPOLATION TECHNIQUE}

In this enchanting world, Image processing techniques plays a vital role processing the digital image in order to make them more sharp and suitable for digital application. These techniques are not only used in image they are also used in internet, multimedia, communication, image resizing and restoring, particularly used for downloading content and used for sharing and editing purposes. Interpolation techniques are strong sampling technique that are the widely used tool in current trend. Image interpolation processing has become versatile and nowadays used in diverse area. Basically image interpolation techniques are used in resizing digital image but not changing the values. Interpolation technique will be useful for researchers, developers and medical practitioner. 


\subsection{Bilinear Interpolation Technique}

In computer vision bilinear interpolation technique is one of the basic resampling technique of image. Bilinear interpolation technique can be considered as the weighted average of intensity $\mathrm{I}\left(\mathrm{X}_{1}, \mathrm{Y} 1\right)$ at point $\mathrm{p}\left(\mathrm{X}_{2}, \mathrm{Y} 2\right)$

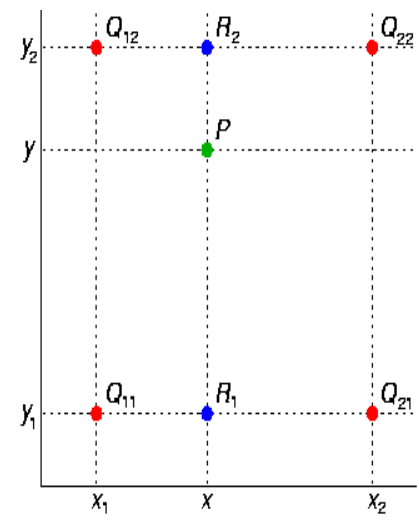

Fig1.4

$\mathbf{P}=$ Desired Point, $\mathbf{Q}=$ Known Points (four closest pixels) $R=$ Point on the line with the known points

Interpolation to find the unknown values at point.

$$
f(R 1) \approx \frac{x-x 1}{x 2-x 1} f(Q 11)+f(Q 21)
$$

Where, $R 1=(x, y 1)$

$$
f(R 2) \approx \frac{x 2-x}{x 2-x 1} f(Q 12)+\frac{x-x 1}{x 2-x 1} f(Q 22)
$$

Where, $R 2=(x, y 2)$

Interpolation in $\mathrm{Y}$ direction

$$
f(P) \approx \frac{y 2-y}{y 2-y 1} f(R 1)+\frac{y-y 1}{y 2-y 1} f(R 2)
$$

Desired estimation of $\mathrm{f}\left(\mathrm{X}_{1}, \mathrm{Y} 2\right)$ are as follow,

$$
\begin{aligned}
& f(x, y) \approx \frac{f(Q 11)}{(x 2-x 1)(y 2-y 1)}+(x 2-x)(y 2-y)+ \\
& \frac{f(Q 21)}{(x 2-x 1)(y 2-y 1)}(x-x 1)(y 2-y)+\frac{f(Q 12)}{(x 2-x 1)(y 2-y 1)}(x 2- \\
& x)(y-y 1)+f(q 22) /(x 2-x 1)(y 2-y 1)=1 /(x 2- \\
& x 1)(y 2-y 1)(f(Q 11)(x 2-x)(y 2-y)+f(Q 21)(x- \\
& x 1)(y 2-y)+f(Q 12)(x 2-x)(y-y 1)+f(Q 22)(x- \\
& x 1)(y-y 1))
\end{aligned}
$$

Firstly by linear interpolation between the two values are calculated to calculate the intensity of the pixel

$$
\begin{aligned}
& I_{20,14.5}=\frac{15-14.5}{15-14} \cdot 91+\frac{14.5-14}{15-14} \cdot 210=150.5 \\
& I_{21,14.5}=\frac{15-14.5}{15-14} \cdot 162+\frac{14.5-14}{15-14} \cdot 95=128.5
\end{aligned}
$$

Later interpolating with the values obtained we get,

$$
I_{2014.5}=\frac{21-20.2}{21-20} \cdot 150+\frac{20.5-14}{21-20} \cdot 128.5=146.1
$$

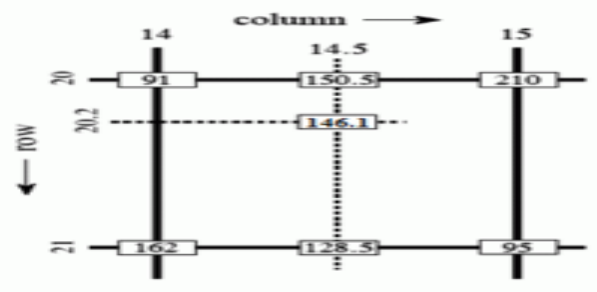

Fig1.5

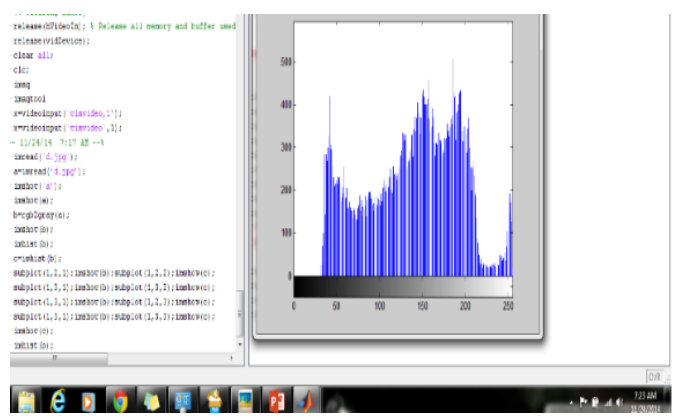

Fig1.6

The algorithm actually reduce the distortion caused by resizing image, following by the histogram of the color samples.

\section{APPLICATION}

\subsection{Mobile computing device:}

The Sixth Sense system uses computing device that act as the processing device that embed all other peripherals to them.[7] The software program enables all features to run in any laptops or any mobile computing device. The device can either be computer or by cell phone. Digital interface device are connected either by wired or by wireless. The detailed working of device are listed below. The mobile device can also be connected to $3 \mathrm{~g}$ or to the internet.

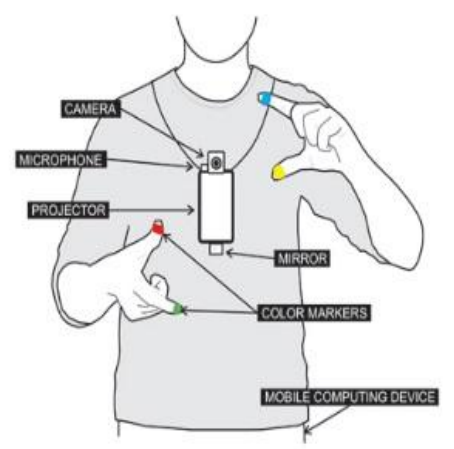

Fig1.7

\subsection{DRAW}

\subsubsection{HOW TO}

Gesture like a "D" from top left to bottom right, draw application will appear.

Hide blue pointer and draw with red marker

\subsubsection{ABOUT}

Drawing application is used not only for drawing, they are used for making notes too. We need not carry any 
book or notepad around. Eraser can be used to delete the data we entered and can chose color fonts etc.

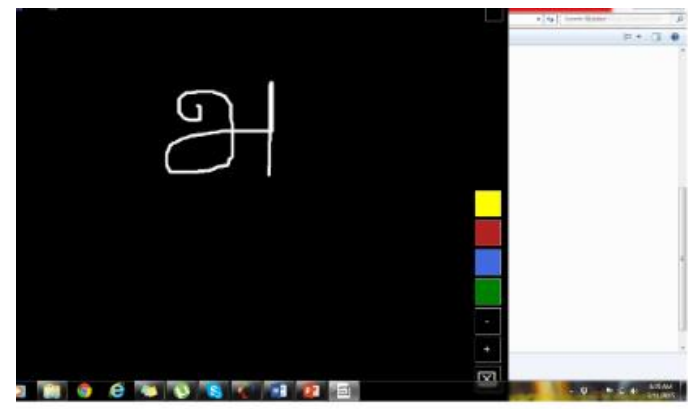

\subsection{Photo application}

\subsubsection{HOW TO}

Gesture like a triangle from top left to bottom right, camera application will appear.

\subsubsection{ABOUT}

Make a rectangle with your color caps and when the gesture is recognized, when the countdown last for three second and that time the user has to remove his hand away from the camera

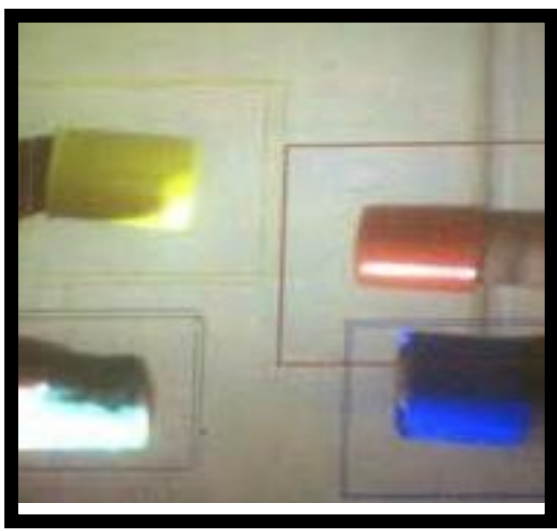

Fig1.8

\subsection{Gallery application}

\subsubsection{HOW TO}

Gesture like " $G$ " from top left to bottom right, Gallery application will appear.

\subsubsection{ABOUT}

Photo captured by the camera are later can be sorted to send mail or can be edited instantly.

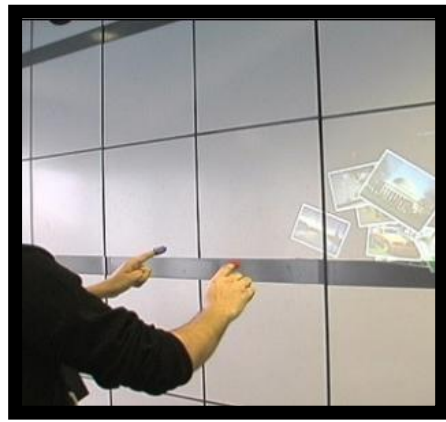

Fig1.9

\subsection{Mail Application}

5.5.1 HOW TO

Gesture like “@” from top left to bottom right, mail application will appear.

\subsubsection{ABOUT}

Displays a list of email from outlook (required that MS Outlook be running for this to work.

\subsection{Weather Application}

\subsubsection{HOW TO}

Gesture like "STAR" from top left to bottom right, Weather application will appear.

\subsubsection{ABOUT}

Displays a weather application that can be localized to your area.

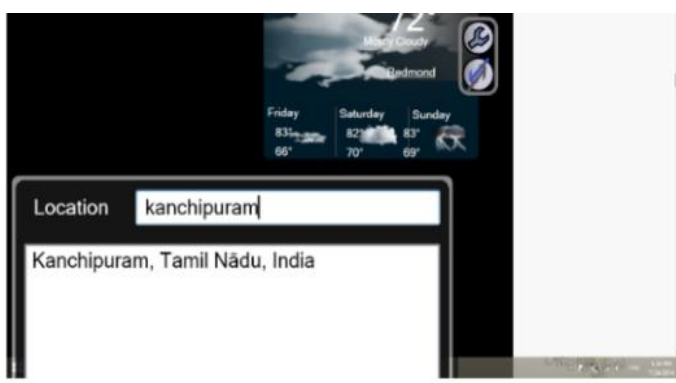

Fig2.0

\subsection{Stock application}

5.7.1 HOW TO

Gesture like "S" from top left to bottom right, stock application will appear.

\subsubsection{ABOUT}

Displays stocks values in live and stock scale can be adjusted using navigator at the bottom of the projected display

\subsection{Newspaper}

\subsubsection{HOW TO}

Gesture like "N" from top left to bottom right, Newspaper application will appear.

\subsubsection{ABOUT}

When the camera recognize the image present in the newspaper they will telecast the video of the image.

\subsection{Book}

\subsubsection{HOW TO}

Gesture like "B" from top left to bottom right, BOOK application will appear.

\subsubsection{ABOUT}

The camera actually takes snap of the book cover search through internet and shows user about the author and the rating of book. 


\subsection{Clock}

\subsubsection{HOW TO}

Gesture like "O" from top left to bottom right, Clock application will appear.

\subsubsection{ABOUT}

Circle gesture using our hand get us to the analog clock. We actually don't need of watch and cell phone to see time

\section{ADVANTAGE}

\subsection{Port Anywhere:}

[7]One of the main advantage of the device is its size and portability .sixth sense device are light in weight and can be carried out without any difficulties. all devices are less in weight and they are portable too, but sixth sense device have multi touch, multi- user interaction and multiple sense are the add-on features of this device. Multi-sensing technique are used to interact more than one color, hence they are more efficient. Sixth Sense technology also in-corporate Multi-user functionality. This kind device can also be used for long interaction scenarios.

\subsection{Cost Effective}

The cost for making the construction of gesture interface device is very low that each and every one can afford to buy themselves.[8] It was made from parts that we use as our daily drive. The gesture interface devices are not yet released for commercial use for the user, once it's released they cost as similar to the price of a basic smartphone.

\subsection{Universal use}

Using Sixth Sense device the user can easily access data from any machine at real time speed. The user require nothing to interact or to access the data. The data are accessed through recognition of hand gestures. Manipulating data using hand recognition is much easier and user friendlier compared to the text user interface or graphical user interface which requires peripherals like keyboard, mouse and monitor. We can project information onto any surface and can work, manage the data as per convenience of the user.

\section{RESULTS}

The experiment was carried out with subjects having varied physique and finger formation. At the end the result varied depending on the position of the hand and how accurately it was placed in front of the camera. The following table shows the results of the experiments.

\begin{tabular}{|c|c|c|c|c|c|}
\hline Task & Environment & expected results & Actual results & Outcome: & sicomments \\
\hline $\begin{array}{l}\text { camela- postion your hands as shown in } 5.3 \text { photo } \\
\text { applicion }\end{array}$ & $\begin{array}{l}\text { just momentis atter sun rise/ sun set } \\
\text { minimal backgound light } \\
\text { Swith on projector /flash }\end{array}$ & $\begin{array}{l}\text { camera should fire } \\
\text { within } 3 \text { sec. }\end{array}$ & $\begin{array}{l}\text { with flash and } \\
\text { projector light, } \\
\text { camera fired as } \\
\text { expected }\end{array}$ & success & \\
\hline $\begin{array}{l}\text { camera- postion your hands as shoun in } 5.3 \text { photo } \\
\text { applicaion }\end{array}$ & $\begin{array}{l}\text { just moments atter sun rise/ sunset } \\
\text { minimal background light: Do not } \\
\text { Switch on projector /flash }\end{array}$ & $\begin{array}{l}\text { camera should fire } \\
\text { within } 3 \text { sec. }\end{array}$ & $\begin{array}{l}\text { without flash and } \\
\text { projector light, } \\
\text { camera did not } \\
\text { fire as expected. }\end{array}$ & failue. & $\begin{array}{l}\text { this means sufficient lighting } \\
\text { has to be available in order } \\
\text { for the application to work } \\
\text { accuately. }\end{array}$ \\
\hline drall-postion your hands as shown in 5.21 & $\begin{array}{l}\text { just moments atter sun rise/ sun set } \\
\text { minimal background lightswitch on } \\
\text { projectorfllash. }\end{array}$ & $\begin{array}{l}\text { drawing application } \\
\text { should appear. }\end{array}$ & As expected & success & \\
\hline drawl-postion your hands as shown in 5.21 & $\begin{array}{l}\text { just moments atter sun rise/ sunset } \\
\text { minimal background lightdo not } \\
\text { Switch on projector:Do not } \\
\text { Swivth on projector flfash }\end{array}$ & $\begin{array}{l}\text { drawing application } \\
\text { should appear. }\end{array}$ & $\begin{array}{l}\text { withoutflash } \\
\text { camera did not } \\
\text { fire as expected. }\end{array}$ & failue. & $\begin{array}{l}\text { this means sufficient lighting } \\
\text { has to be available in order } \\
\text { for the application to work } \\
\text { accurately. }\end{array}$ \\
\hline Gallenp posstion pour hands as shown in 5.41 & $\begin{array}{l}\text { just moments ater sun rise/ sun set } \\
\text { minimal backgound lightswitch on } \\
\text { projectorfflash. }\end{array}$ & $\begin{array}{l}\text { Gallery application } \\
\text { should appear. }\end{array}$ & As expected & success & \\
\hline Gallerp postion pour hands as shown in 5.41 & $\begin{array}{l}\text { just momentis atter sun rise/ sunset } \\
\text { minimal backgound lightdo not } \\
\text { Switch on projector:Do not } \\
\text { Switch on projector /flash }\end{array}$ & $\begin{array}{l}\text { Galley application } \\
\text { should appear. }\end{array}$ & $\begin{array}{l}\text { withoutflash } \\
\text { camera did not } \\
\text { fire as expected. }\end{array}$ & failue. & $\begin{array}{l}\text { this means sufficient lighting } \\
\text { has to be available in order } \\
\text { for the application to work } \\
\text { accurately. }\end{array}$ \\
\hline Mail- postion your hands as shown in 5.51 & $\begin{array}{l}\text { just moments atter sun rise/ sun set } \\
\text { minimal background lightswitch on } \\
\text { projectorflash. }\end{array}$ & $\begin{array}{l}\text { Mail application } \\
\text { should appear. }\end{array}$ & As expected & success & \\
\hline Gallerp postion pour hands ass shown in 5.51 & $\begin{array}{l}\text { just moments atter sun rise/ sunset } \\
\text { minimal backgound lightdo not } \\
\text { Switch on projector:Do not } \\
\text { Switch on projector fllash }\end{array}$ & $\begin{array}{l}\text { Mail application } \\
\text { should appear. }\end{array}$ & $\begin{array}{l}\text { withoutflash } \\
\text { camera did not } \\
\text { fire as expected. }\end{array}$ & failue. & $\begin{array}{l}\text { this means sufficient lighting } \\
\text { has to be available in order } \\
\text { for the application to work } \\
\text { accurately. }\end{array}$ \\
\hline Weather postion your hands as shown in 5.61 & $\begin{array}{l}\text { just momentis atter sun rise/ sun set } \\
\text { minimal backgound lightswitch on } \\
\text { projectorfflash. }\end{array}$ & $\begin{array}{l}\text { Weather application } \\
\text { should appear. }\end{array}$ & As expected & success & \\
\hline Weather- postion you hands as shoun in 5.61 & $\begin{array}{l}\text { just moments atter sun nise/ sunset } \\
\text { minimal background lightdo not } \\
\text { Switch on projector:Do not } \\
\text { Switch on projector /flash }\end{array}$ & $\begin{array}{l}\text { Weather application } \\
\text { should appear. }\end{array}$ & $\begin{array}{l}\text { without flash } \\
\text { camera did not } \\
\text { fire as expected. }\end{array}$ & failue. & $\begin{array}{l}\text { this means sufficient lighting } \\
\text { has to be available in order } \\
\text { for the application to work } \\
\text { accurately. }\end{array}$ \\
\hline Stock-postion your hands as shown in 5.7 .1 & $\begin{array}{l}\text { just moments ater sun rise/ sun set } \\
\text { minimal background lightswitch on } \\
\text { projectorfflash. }\end{array}$ & $\begin{array}{l}\text { Stock application } \\
\text { should appear. }\end{array}$ & As expected & success & \\
\hline Stock-postion your hands as shown in 5.7 .1 & $\begin{array}{l}\text { just momentis atter sun rise/ sunset } \\
\text { minimal backgound lightdo not } \\
\text { Switch on projector:Do not } \\
\text { Switch on projector /flash }\end{array}$ & $\begin{array}{l}\text { Stock application } \\
\text { should appear. }\end{array}$ & $\begin{array}{l}\text { without flash } \\
\text { camera did not } \\
\text { fire as expected. }\end{array}$ & failue. & $\begin{array}{l}\text { this means sufficient lighting } \\
\text { has to be available in order } \\
\text { for the application to work } \\
\text { accurately. }\end{array}$ \\
\hline Neurspaperer postion your hands as shown in 5.81 & $\begin{array}{l}\text { just momentis atter sun rise/ sun set } \\
\text { minimal background lightswitch on } \\
\text { projectorflfash. }\end{array}$ & $\begin{array}{l}\text { Newspaper } \\
\text { application should } \\
\text { appear. }\end{array}$ & As expected & success & \\
\hline Neusspaper. postion your hands as shoun in 5.81 & $\begin{array}{l}\text { just momentis atter sun rise/ sunset } \\
\text { minimal background lightdo not } \\
\text { Switch on projector:Do not } \\
\text { Switch on projector /flash }\end{array}$ & $\begin{array}{l}\text { Neuspapper } \\
\text { appliction should } \\
\text { appear. }\end{array}$ & $\begin{array}{l}\text { without flash } \\
\text { camera did not } \\
\text { fire as expected. }\end{array}$ & failure. & $\begin{array}{l}\text { this means sufficient lighting } \\
\text { has to be available in order } \\
\text { for the application to work } \\
\text { accurately. }\end{array}$ \\
\hline Book-postion your hands as shown in 5.91 & $\begin{array}{l}\text { just moments atter sun rise/ sun set } \\
\text { minimal background lightswitch on } \\
\text { projectooflfash. }\end{array}$ & $\begin{array}{l}\text { Book application } \\
\text { should appear. }\end{array}$ & As expected & success & \\
\hline Book-postion your hands as shown in 5.9 .1 & $\begin{array}{l}\text { just moments atter sun rise/ sunset } \\
\text { minimal background lightdo not } \\
\text { Switch on projector:Do not } \\
\text { Switch on projector /flash }\end{array}$ & $\begin{array}{l}\text { Book appliction } \\
\text { should appear. }\end{array}$ & $\begin{array}{l}\text { without flash } \\
\text { camera did not } \\
\text { fire as expected. }\end{array}$ & failure. & $\begin{array}{l}\text { this means sufficient lighting } \\
\text { has to be avail able in order } \\
\text { for the application to work } \\
\text { accurately. }\end{array}$ \\
\hline Clock-posstion your hands as shown in 5.10 .1 & $\begin{array}{l}\text { just moments atter sun rise/ sun set } \\
\text { minimal backgound lightsswitch on } \\
\text { projectoofflash. }\end{array}$ & $\begin{array}{l}\text { Clock application } \\
\text { should appear. }\end{array}$ & As expected & success & \\
\hline Clock-postion your hands as shown in 5.10 .1 & $\begin{array}{l}\text { just moments atter sun rise/ sunset } \\
\text { minimal background lightdo not } \\
\text { Switch on projector:Do not } \\
\text { Switch on projector /flash }\end{array}$ & $\begin{array}{l}\text { Clock application } \\
\text { should appear. }\end{array}$ & $\begin{array}{l}\text { without flash } \\
\text { camera did not } \\
\text { fire as erpected. }\end{array}$ & failue. & $\begin{array}{l}\text { this means sufficient lighting } \\
\text { has to be available in order } \\
\text { for the application to work } \\
\text { accurately. }\end{array}$ \\
\hline
\end{tabular}

\section{CONCLUSION}

Sixth sense recognizes the object and display information relevant to the gesture and letting us to access it in any way we need The sixth sense device contain several application that demonstrate the usefulness, flexibility, viability of the 
system. Sixth sense device allow us integrate machine using hand gestures. The potential of becoming the ultimate GUI transparently helps in accessing information about everything around us.

\section{REFERENCES:}

[1] Relevant feature for video based continuous sign language recognition. Department of Technical Computer Science, Aachen University of Technology Aachen, Germany, 2000.

[2] Building temporal models for gesture recognition. In proceedings British Machine Vision Conference, 2000, pages 32-41.

[3] Use your hand as a 3-D mouse or relative orientation from extended sequences of sparse point and line correspondences using the affine trifocal tensor. In proceedings 5th European Conference on Computer Vision, 1998, pages 141-157.

[4] O. Castillo, O. and P. Melin, "A New Approach for Plant Monitoring using Type-2 Fuzzy Logic and Fractal Theory", International Journal of General Systems, Taylor and Francis, Vol. 33, 2004, pp. 305- 319.

[5] S. Furui, "Cepstral analysis technique for automatic speaker verification", IEEE Transactions on Acoustics, Speech and Signal Processing, 29(2), 1981, pp. 254- 272.

[6] Intelligent Image Processing, John Wiley and Sons, pp.384, 02001NOV02, ISBN 0-471-40637-6 sixth sense. Pranav Mistry.
[7] WUW - wear Ur world: a wearable gestural interface", Proceedings of CHI EA '09 Extended Abstracts on Human Factors in Computing Systems Pages 4111-4116, ACM New York, NY, USA

[8] MIT Media Lab Technical Report 260, December 1994

[9] Intelligent Image Processing, Wiley, 2001

[10] Goswami, Kapil Dev (April 2014). "Gesture Based Interfacing" . Engineering Research Publication 1: 211214. Retrieved 12 August 2014

[11] Prof. Mr. D.S. Patil1, Mr. Shahak Patil2 Sixth Sense Technology-A New Innovation

\section{AUTHOR's PORFILE}

GuruVenkatesh is a final year student of B.Tech in SCSVMV University. He has keen interest in IMAGE PROCESSING \& AI. Presently he is working in Gesture based digital device

Bharatwaj V is a final year student of B.Tech in SCSVMV University. He has keen interest in IMAGE PROCESSING \& AI. Presently he is working in Gesture based digital device.

K Srinivasan is working as Assistant Professor in IT Dept. of SCSVMV. HE IS KEEN INTEREST ON IMAGE PROCESSING, ARTIFICIAL INTELLIGENCE. 